DE

\title{
LOCATIONE CONDUCTIONE
}

\section{ATQUE EMPHYTEUSI GRAECORUM.}

\author{
SCRIPSIT \\ GAROLUS EULER.
}

(DISS. INAUG. LIPS.)

GISSAE MDCCCLXXXII.

APUD J. RICKERUM. 
